\title{
The Uses of Amateurs:Travel Writing as a Tool of Second Language Acquisition Research
}

\author{
Patrick Lenahan ${ }^{\mathrm{a}^{*}}$ \\ ${ }^{a}$ Department of English, University of Pretoria, South Africa \\ *patrick.lenahan@up.ac.za
}

\begin{abstract}
In order for second language acquisition (SLA) research to access the "learner-internal functions' of SLA, methodologies of introspective research have arisen, including 'diary studies' and 'language learner histories'. These have been found to yield valuable data about SLA (particularly in respect of affective factors and learning strategies), and are most rewarding when they approximate to quasi-literary modes of self-presentation: highly personalized and richly contextualized. This article proposes that the body of data that has accumulated from this initiative could be further expanded by including non-specialist accounts of language learning which share many of the conditions and features of diary studies, specifically works of travel literature in which part of the travellers' experience is learning local languages. The article first attempts to illustrate this common ground by means of comparative samples, and then demonstrates from further texts how travel writing, though not produced by SLA specialists, can be analysed in terms of SLA theory so as to yield its own insights that not only corroborate what the specialist diary studies have revealed, but also supplement or challenge them. The article concludes that there is in this growing body of work a hitherto untapped resource of SLA research that awaits more sustained attention.
\end{abstract}

Key words: affective factors, communication strategies, diary studies, language learning strategies, second language acquisition, travel writing

Ever since the great paradigm shift in the field of second language acquisition (SLA) forty years ago, from the domination of behaviourism to that of cognitivism, researchers have had to contend with the basic problem of accessing the language learning process, the very stuff of their subject. No longer seen as the formation of a set of habits by learners through the imitation of speech heard around them (that is, an external process), the learning process came to be understood as a largely internal operation whereby language is derived by each learner from an innate linguistic 'device' in the human brain. Unlike the behaviourists, to whom all that mattered for research purposes was what they could see in terms of language behaviour, to the succeeding generations of researchers what has mattered is what can't be seen going on, but is hidden away: all the 'learner-internal functions' (Ellis 1985, 42). Among the ways devised to access the so-called 'black box' where these functions are centred, were introspective research methods of data collection and 
analysis (Faerch and Kasper 1987). Introspective methods such as think aloud protocols, diary studies, learner histories and retrospective interviews 'allowed researchers to peer into the private thoughts, expectations, and attitudes of learners, in ways that observations and quantifiable scales could not' (Pellegrino 1998, 92). Although not without their detractors from the start, these introspective methods were quickly recognized as promising 'valuable insights', especially into the affective aspects of language learning, and also having 'a great deal of potential for the investigation of learning strategies', and 'a valuable place in the overall methodological repertoire of the language researcher' (Nunan 1992, 121, 124). These predictions have been fulfilled: introspective methods are now a standard part of SLA research handbooks (Dörnyei 2007; Richards and Schmidt 2010; Hinkel 2011), and current reviews confirm that they are indeed 'providing a rich, full picture of learning, particularly the social and cognitive dimensions of learners from their particular point of view' (Barkhuizen et al. 2014, 35; my emphasis). The reference here to the 'social' and the 'particular' as the special focus of diary studies points to one reason for their current popularity, since in the last decade SLA research in general has seen a prioritizing of precisely these aspects. Benson and Nunan, in the suggestively titled Learners' stories: Difference and diversity in language learning, report the shifted focus 'away from "the learner" as an abstract or universalized construct, to actual learners and their historically and contextually situated experiences of learning' $(2005,18)$.

It is by means of diary studies and learner histories that the 'stories' of learning experiences are told and analysed, and it is indeed precisely as forms of narrative that these introspective research methods are now valued (Bell 2002; Pavlenko 2002; Barkhuizen et al. 2014). In fact, diary studies were from the start part of a much broader historical development in qualitative research that has come to be known as the 'narrative turn' (Denzin and Lincoln 2011, 3). The turn to narrative enquiry and storytelling as research methods occurred in the 1980s, when across the social sciences narrative was recognized as ideally suited to the new preoccupation with capturing existence as situated action - since 'narratives or (auto)biographies focus on the description and analysis of social phenomena as they are experienced within the context of individual lives' (Nunan and Choi 2011, 226). Central to this new autobiographical orientation in qualitative research was an interest in the 'voice' of the researcher/narrator, reconceived as the very antithesis of the 'invisible' agent of quantitative tradition who remained an objective outsider. By contrast, the new researchers 'are insiders - very much part of the research process. The objective pronoun "one" is exchanged for the subjective "I"' (p. 225). Self-effacement is replaced by an acute and fascinated self-attentiveness, as the researcher/narrator records and reflects on events and experiences, feelings, thoughts and interactions, in order to build as richly detailed, unashamedly personal a representation as possible of whatever is under investigation. Given the new interest in narrative and narrators in qualitative research, it was perhaps inevitable that the more adventurous proponents would invoke literature as a model of what was wanted, a means of capturing what Lawrence Stenhouse in 1983 called 'the 
texture of reality' which he associated exclusively with fictional narrative, believing that it could 'not be achieved in the reduced, attenuated accounts of events which support quantification' (quoted in Nunan and Choi 2011, 227).

In the context of SLA research, this thinking was reflected in the earliest accounts of diary studies, such as that by Bailey and Ochsner (1983). Because their description seems to convey the originality of the approach more effectively than the more dutiful definitions in current guides (Dörnyei 2007; Barkhuizen et al. 2014), it is used here. For Bailey and Ochsner, the diary study involves a strong projection of the writer's personality, with all its 'qualities, traits and attitudes that affect language learning'. Through this detail, the diarist 'characterizes his own personality' (p. 191) as something 'real and believable', that we can 'identify with, in much the same way that a reader identifies with a fictional character' ( $p$. 192). Furthermore, a good diary will also describe the language learner's physical and social circumstances in enough detail to convey something of the wider context in which the learning takes place and which may well have an influence on it (p. 195). And finally, to ensure that the reader will 'identify' closely with the learner, an informal mode of expression will be used which is as far as possible from that of the 'social science report' with its use of third-person reference and subject jargon (p. 193). All these features of the good SL diary - the confiding voice, the richly textured setting, the projection of the self almost as 'a fictional character' (p. 192) - give the impression of the diary study (or language learner history) as a quasi-literary undertaking. And in fact Bailey and Ochsner quite explicitly assert this: 'diary studies are like an art genre' they say (p. 188), and further, 'in a literary sense, the diarist recreates experience, and this recreation is open to our textual criticism as critical readers' (p. 196).

One such diary study, the now almost legendary project by Schmidt and Frota (1986) recorded the experience of an American learning Portuguese in Rio de Janeiro. It is particularly notable for the way in which it draws the reader into a whole individual existence, conveyed through the detail of place, character and social interaction - in other words, the 'texture of reality':

\section{Journal entry, Week 2}

I hate the feeling of being unable to talk to people around me. I'm used to chatting with people all day long, and don't like this silence. Language is the only barrier since it is certainly easy to meet Brazilians. I've noticed that it is acceptable to ask anyone on the street for a cigarette ... If I take a pack to the beach, it disappears within an hour, so that's 20 people I could have met ... Today P and I were at the beach, a guy came up for a cigarette, sat down and wanted to talk. He asked if I were an American and I said sim. He said something I didn't comprehend at all, so I didn't respond. He said, 'well, obviously communication with you would be difficult' ... and left. 
$\mathrm{H}$ and $\mathrm{I}$ ate dinner at Caneco 70. he complained non-stop about his job. I tried to say 'you don't seem comfortable' with the job ... and his face showed complete noncomprehension. I grabbed my dictionary. 'Comfortable' is comfortavel, but it flashed through my mind that perhaps you can only say chairs are comfortable, not people ... So I learned something, but in general $\mathrm{H}$ is a terrible conversationalist for me ... When I don't understand him, all he can ever do is repeat. (In Nunan 1992, 121-123)

While the classroom experiences recorded in the diary are not reflected here, these extracts do highlight something else important for present purposes. In their evocation of unfamiliar settings, the challenges posed by incomprehensible company, and the ingenuities and frustrations of coping with them - in short, their conjuring of the sheer foreignness of the diarist's world - they raise the possibility that if diary studies do resemble literature, it may be the kind of literature that is especially concerned with foreign experience, and that is travel writing. 'More acutely than any other genre,' one of its theorists has written, 'travel writing is defined by the interaction of the human subject with the foreign in acts of (inter) cultural perception and construction, in processes of understanding and misunderstanding (Korte 2000,5$)$. This seems a fairly accurate description of what is going on in the Brazilian diary study, although of course there is in diary studies the priority above all else of one particular kind of experience, the linguistic. But this in no way lessens their connection with travel writing, because travellers have their own obvious interest in language learning: in fact, for the travel literature theorist Michael Cronin, 'the relationship of the traveller to language is the fundamental aspect of travelling' (Cronin 2000, 2). In so far as travel writing narrates the subjects' developing relationship with the foreign language, there is the possibility that it will resemble diary studies as much as diary studies resemble travel writing, and serve some of their functions.

This resemblance can be shown at once by juxtaposing the Brazilian diary study with the following extracts taken from a work of travel writing by Tony Cohan, On Mexican time: A new life in San Miguel:

Mexico opens up to us to the degree that our Spanish advances. I've reached the last third of Madrigal's Magic Key to Spanish on my own ... I can now speak of things that happened yesterday, though when I do I'm still inclined to attribute something I did to you and vice versa. As for the Spanish future, it still lies ahead ... even though I've discovered I can regularly rely upon 'voy $a$ ' ('I'm going to'), followed by the infinitive, to skirt the problem.

We take our new verbs and ideas into the town, speak only Spanish to each other until our minds get tired or we forget. Some days my Spanish rises to surprising heights. Riding back from Guanajuato with Vicente Arias ... a burst of lucidity possessed me like a poltergeist ... The verbs flew. When I had no word, I'd bide time 
with 'come se dice' - 'how do you say it ...' - fishing for a Latinate English equivalent that often fits, or else letting Vicente feed me the word. ([1999] 2000, 98-99)

This travel narrative seems to display a very comparable 'texture of reality' to that of the diary study: the same embedding in a fully realized locale of language learning that is both described and reflected upon; crucially also, there is the same projection of the writer's personality: the moods, attitudes, traits and ploys that make up the affective dimension that introspective research prizes. This self-focus is of course expected of the diarist, but it is also a large part of travel writing, which is itself 'a form of autobiography' according to its theorists, in which not only 'the travelled world, but the travelling subject is always laid bare' (Hulme and Youngs 2002, 79; Korte 2000,6). The detailed self-exposure of the language learner/traveller conveyed in his whole enmeshing reality - Brazilian or Mexican is what forms the strongest link between these two texts of such different origins.

Particularly in the travel writing, the 'contextually situated experiences of learning' (referred to above as now so prized in SLA research) is a strong element, even if the travel writers lack the linguistic expertise of diary study writers when it comes to the actual language learning itself. And even this inexpertise may be an advantage, since there has been criticism that introspective accounts, being written largely by the researchers themselves, are not representative enough of the experiences of ordinary learners (Nunan 1992, 123). In the field of SLA the watch-words are 'difference and diversity' (Benson and Nunan 2005, 3), and casting the net wide to include along with the language professionals a fair share of amateurs can only help this cause.

As travel writers themselves admit, no other kind of writing is quite as amateurish as theirs. Indeed for Evelyn Waugh, amateurism was nothing less than the 'essential tradition' of English travel writers, visible in their accounts of local history, politics, religion, art, architecture, natural history, ethnography - about none of which they were actually qualified to speak at all (Hulme and Youngs 2002, 88). Expanding on the idea, another travel writer, Colin Thubron, sees amateurism as paradoxically the most valuable function of the travel writer, whose 'role as a leftover amateur' permits insights denied the more jaded professionals: '[the traveller's] situation is different, and his descriptions bear a different value. An outsider, he reaches his destination wide-eyed. His senses are charged and heightened ... And because he is independent of his surroundings, he brings to them other eyes, other frames of reference' (Thubron 1999, 12). Thubron is thinking of travel writers as outsiders in foreign lands, of course, but also as outsiders in the specialist fields they comment on. If one of these fields is language acquisition, it is possible that travellers might bring 'other eyes' and 'senses charged' to this as well, and so record things in a way that not simply supplements what is already known, but as something wholly new.

If the travel writers themselves do not observe and record their language learning experiences from a professional SLA perspective, their observations and records may still be read and understood in terms of SLA theory, and it is a very brief demonstration of how this 
might work that will shortly follow. In the context of SLA theory, the focus will be on the affective dimension of language learning and on learning strategies, both of which have been the particular concerns of diary studies (Turzonska 2014, 75) and which will appear in these travelogues also. By learning strategies is meant the ways in which learners infer, test out and so develop their interlanguage rule-system, and then seek out ways to use it communicatively. Allied to this are communication strategies, which are vital in starting and maintaining communication flow. The identification of these features in the texts follows the comprehensive surveys of the field by Ellis $(1985 ; 1994 ; 2008)$, which remain the most authoritative and convenient. Ellis is used to illuminate technical details of extracts from two travel works, but the more important aim is to show how Ellis (and SLA theory in general) may be illustrated and (ideally) augmented, complicated and enriched by the travel works that from this perspective are simply more narratives of language learning. And the array of such narratives is truly vast. They fall into at least four groups. First are the so-called 'Iong-stay' travel books, such as Frances Mayes's Bella Tuscany: The sweet life in Italy (1999) or Derek Lambert's promisingly titled Spanish lessons: Beginning a new life in Spain (2000). Secondly, 'study abroad'works describe the linguistic adventures of exchange students, such as Charlotte Hobson in Black earth city: $A$ year in the heart of Russia (2001). Thirdly, 'work abroad' travel books are typically accounts by volunteers in Third World communities such as Sarah Erdman's, Nine hills to Nambonkaha: Two years in the heart of an African village (2003), or anthropologists' experiences of what James Clifford $(1997,67)$ has called 'fieldwork as travel encounter', such as Dennis Werner's Amazon journey: An anthropologist's year among Brazil's Mekranoti Indians (1990). Finally, there are the books that recount the English language learning experiences of immigrants from foreign countries - a kind of 'reverse' travel writing, exemplified by Eva Hoffman's Lost in translation: A life in a new language (1989) and Ariel Dorfman's Heading south, looking north: A bilingual journey (1998). All these sub-genres are fuzzy, but help to impose some order on a sprawling and ever-growing literature. The important point is that, at least at this stage of the initiative, the research net should be cast over that literature as widely as possible, and the sense of what constitutes useful 'introspective' data kept as loose as possible.

The first of the two samples from this literature to be looked at will reuse for economy's sake the extract already cited from Cohan's On Mexican time. Its first function for us might be simply to show just how closely travelogue data on language learning can correspond to the professional record. The key aspect in the excerpt is the writer's 'discovery' of a learning strategy he 'relies upon' when coping with Spanish tenses: 'I can now speak of things that happened yesterday ... [but] as for the Spanish future, it still lies ahead, a distant shimmering oasis - even though I've discovered I can regularly rely upon "voy a" ("I'm going to"), followed by the infinitive to skirt the problem' $(1999,97)$. As it happens, Cohan's reliance on the Spanish future form voy $a$ is actually documented in the SLA literature as a simplification strategy, and illustrated there by another learner who, precisely like Cohan, used 'the "going to" form in French to express future meaning, simply because he found it 
easier to learn' (Ellis 1985, 171). This French learner is cited by Ellis in a discussion of how learners, when forming hypotheses about grammar rules, deliberately simplify the system (here the future) in order to reduce the 'learning burden' (p. 171) - which seems to be Cohan's case also. However, there may be slightly more to Cohan's contribution than merely this corroborative illustration. The learning strategy of simplification is in fact a controversial one in the literature, and Cohan's use of it might in fact have bearing on the issue. For some theorists believe that this form of simplification of the Spanish (or French) future to 'going to' is not a tactic of language learning at all, but more like a form of non-learning, a way of avoiding the proper structures rather than acquiring them. And indeed, Cohan makes explicit the intention to avoid tackling a complex form when he states his reason for using the simplified version: 'to skirt the problem' he says. So, what at first seems in Cohan's account to be a straightforward illustration of a standard concept (a certain learning strategy), begins to look more like evidence for challenging that concept.

The potential of travel writing to challenge and complicate received notions seen here will be returned to in the second work, below. But before this Mexican work is put aside, another of the extracts can be used briefly to illustrate the use of a different aspect of language learning: the communication strategies. The writer describes his conversation with a friend:

Riding back from Guanajuato with Vicente Arias ... a burst of lucidity possessed me like a poltergeist ... the verbs flew. When I had no word, I'd bide my time with 'como se dici' - 'how do you say it ...' fishing for a Latinate English equivalent that often fits, or else letting Vicente feed me the word. (98-9)

'When I had no word, I'd bide my time'. All communication strategies are triggered by fluency failure, and all of them have to do with one key imperative: 'to keep the channel open' (Ellis 1985, 187). This is exactly what Cohan illustrates with his tactics of 'biding time' when words fail him: first he uses the option of formulaic speech ('como se dici'); then attempts the compensatory strategy of foreignizing ('fishing for a Latinate English equivalent'), and finally resorts to the co-operative strategy of indirect appeals for help ('letting Vicente feed me the word').

Limited in themselves, each short extract can be linked to others combed from similar works, and their value will lie in their cumulative effect, similar to what is envisaged for the more conventional introspective data collection: 'the possibility' as Bailey says, 'of aggregating diary studies' for their significant patterns $(1983,190-191)$. Thus, as a very small example of this, the display of communicative strategies in the Mexican extract correlates closely with a similar account of strategies noticed in herself by another travel writer, Frances Mayes, in Bella Tuscany $(1999,295)$. But travel texts, at their best, can offer more than this collective data-bank of extracted fragments, because there are also single travelogues that are full, varied and sustained enough on their own to supply data for SLA research purposes that is similar to a complete case study. 
River town: Two years on the Yangtze (2001) is Peter Hessler's account of his experiences as a Peace Corps English teacher in China. Although not a language specialist, he was motivated to travel to China partly by the desire to learn the language, as he explicitly states $(2001,60)$, and it is perhaps this that gives his language experiences a special emphasis in his book, where he is so ready to introspect, to monitor and report his learning just as the professional methodologies require; and what he discovers seems quite as original and suggestive in the context of the SLA literature as anything produced professionally in that literature.

Hessler decided on a double approach to learning Chinese: classroom-based and naturalistic (through unstructured interactions), and it is the data from the latter that is especially valuable, complementing the professional SLA research which tends to focus on classroombased experiences (Ellis 1994, 550). In his account, Hessler's attempts to interact in Chinese with the locals are at first difficult and then increasingly traumatic for him ('the shouts, the mocking calls'), to a degree not hinted at in the professional literature. And in fact it is his description (pp. 65-72) of what might be termed the psychopathology of naturalistic language learning that stands out, and particularly its corrosive effects on his self-esteem, or more generally, his 'self-concept' (Williams and Burden 1997, 97). So, for example, one surprising result of his own linguistic incompetence is an almost morbid fascination with other people's ordinary skills: 'I watched [them] work with all the voyeur's impotent envy' (p. 71). He overcomes this, however, through his own ingenuity, being an example par excellence of what the SLA literature terms 'autonomous learners' who 'take charge of their own learning' (Ellis 1994, 546-549). More than anything else, Hessler emerges from the record as a resourceful learner, able not only to devise his own programme, but also to deal with difficulties through 'learning strategies' he improvises as he goes along. So, when he feels confident enough to return to the town to 'seek opportunities' for speaking, he now does so knowing that naturalistic learning requires its own strategies if it is to work:

I realized that the key was finding places I went to regularly - it was no good just to wander around downtown Fuling, because that way I attracted too much attention and the passersby shouted at me. It was better to go to the same places at the same times every week, and then people became accustomed to me and it was easier to have conversations. (p. 140)

An important insight here is that the strategy for ensuring constructive talk focuses not on the learner as we might have assumed (needing confidence building, and encouragement), but on the native speakers. It is their participation (not the learner's) that has to be carefully prepared, they (not the learner) who have to be given time to 'become accustomed' to talking to a foreigner, lest they take fright or (as in the early stages) turn nasty. It is the native speaker's needs that must be catered for by the learner, and not the other way round. In fact Hessler's account as a whole is intriguingly marked by just such unexpected reversals of standard SLA assumptions. Thus, for example, his experience convinces him that 
the learner, far from needing to actively 'seek out' opportunities for language use, should adopt a passive role: 'it was a matter of developing patience and trust. I had to allow things to happen - if somebody approached me, I talked to him ... I couldn't expect to control every situation' (p. 193). Paradoxically then, the appropriate strategy is to have none at all something one certainly wouldn't find anywhere in the SLA literature. And indeed even for him as its advocate this method presents difficulties, because it goes against his natural instincts: 'I had never been a passive person, and it took most of the spring to become comfortable with this role ... at last I accepted that things happened best when I let them happen' (p. 193).

In fact, the adoption of a new role, even a whole new identity, becomes a key aspect of Hessler's language learning in more ways than one, and it is his account of the emergence of a separate SL personality - a Chinese Peter Hessler - that is probably the most intriguing part of his entire self-portrait, and can in fact be linked to a growing interest in the issue of identity and 'constructing the self' in SLA research (Pellegrino 2005; Benson et al. 2013). When Hessler slowly begins to find his interactions in town getting easier, he at first attributes it to a change in the townspeople, but then grasps the truth:

I was the one who had really changed. I was a new person, Ho Wei ... the name I had been given during Peace Corps training ... My Chinese name had no connection to my American name, and the person who became Ho Wei had no connection to my American self. There was an enormous freedom in that ... at the age of twenty-eight, I suddenly had a completely new identity. (237-238)

The SLA literature documents 'fear of losing oneself' or 'reduced personality' as a source of debilitating anxiety (Ellis 2008, 692-693), but clearly for Hessler it has a wholly positive effect of freeing him from his normal inhibitions, partly bound up with his role as English teacher. And in exchanging this persona for the other, he is released into the kind of unselfconscious interaction that brings fluency:

Ho Wei was completely different from my American self: he was friendlier ... he was funny ... Ho Wei was stupid, which was what I liked the most about him. He spoke with an accent; he had lousy grammar; and he laughed at the simple mistakes that he made. People were comfortable with somebody that stupid, and they found it easy to talk with Ho Wei. (238-239)

What is most striking here is that it is not only the learner who is freed from his inhibitions by the persona, but the native speakers also freed from theirs. Again, Hessler's key theme emerges: a re-conceiving of the learner-native speaker relationship, in terms of which the native speaker needs to be coaxed into interactions. So here it is not the learner who is described as feeling 'more comfortable', or as finding it 'easy to talk', but the native speakers. In perhaps what is his most radical inversion, Hessler seems to suggest that it is not (or at least not solely) 'learner variables' that influence learning, nor the learner's 
'affective filter' that has to be lowered to allow learning, but those of the native interlocutors.

Of the strange, split personality that is involved in the learning, Hessler finally says: 'Ho Wei and Peter Hessler never met each other. The notebook was the only thing they truly shared' (p. 239). This notebook is what is used by Ho Wei to record his language learning experiences as they happen in the street, and then again by Peter Hessler to type up the day's events into what will ultimately become the work of travel literature we have in front of us. As he says, the notebook links the two sides of Hessler's personality. But more importantly for us, this notebook that is both a language-learning diary and the draft of a travelogue may also be taken as an emblem of a more fundamental connection: that between travel writing as such and SL learner diaries, which has been explored in this article. In the new 'narrative-friendly' mood prevailing in qualitative research, modes of narrative enquiry like diaries and learner histories are widely acknowledged as useful tools of SLA research, and are thought to be more effective the closer they resemble literary texts. In this article, a further step has been taken by suggesting that we need not stop with narratives that are like literature, but include as tools the literature which diary studies and learner histories resemble (or one of the kinds of literature: there are other analogous kinds), and that is travel writing. There is running through these travel narratives a rich seam of SLA data that waits to be exploited. A work like Hessler's is an example of the quality of the material that travel writing can contribute, and what has been touched on here is by no means unique. Most travel writers of the long-stay variety pick up the local language and this experience often becomes interwoven with the larger interior story that always complements their outdoor lives. As the travel writer Norman Douglas put it, 'the reader of a good travel-book is entitled not only to an exterior voyage ... but an interior ... so that the ideal book of this kind offers us indeed a triple opportunity of exploration - abroad, into the author's brain, and into our own' (in Korte 2000,6). Insofar as these travels around the author's brain take place in that part of it where language learning goes on - the so-called 'black box' - they also can be counted as a useful adjunct to introspective SLA research. And this research, with its daunting challenge of accessing the internal processes of language learning, needs whatever assistance it can get. As the SLA theorist Rod Ellis complains, "peering into the "black box" ... is rather like stumbling blindfold around a room to find a hidden object' $(1985,188)$. Travel writers might give new sight, and new insights, in the field although - or perhaps because - they are amateurs.

\section{References}

1. Bailey, Kathleen M. and Robert Ochsner. 1983. A methodological review of the diary studies: Windmill tilting or social science? In Second language acquisition studies. ed. K. M. Bailey, M. H. Long and S. Peck, 188-198. Rowley MA: Newbury House. 2. Barkhuizen, Gary, Phil Benson and Alice Chik. 2014. Narrative inquiry in language teaching and learning research. London: Routledge. 
3. Bell, Jill Sinclair. 2002. Narrative inquiry: More than just telling stories. TESOL Quarterly 36 (2): 207-213. doi: 10.2307/3588331

4. Benson, Phil and David Nunan. eds. 2005. Learners' stories: Difference and diversity in language learning. Cambridge: Cambridge University Press.

5. Benson, Phil, Gary Barkhuizen, Peter Bodycott and Jill Brown. 2013. Second language identity in narratives of study abroad. London: Palgrave Macmillan.

6. Clifford, James. 1997. Routes: Travel and translation in the late twentieth century. Cambridge, MA: Harvard University Press.

7. Cohan, Tony. 2000. On Mexican time: A new life in San Miguel. London: Bloomsbury.

8. Cronin, Michael. 2000. Across the lines: Travel, language and translation. Cork: Cork University Press.

9. Denzin, N. and Y. Lincoln. 2011. Introduction: The discipline and practice of qualitative research. In The Sage handbook of qualitative research (4th edition). ed. N. Denzin and Y. Lincoln, 1-21. Thousand Oaks, CA: Sage Publications.

10. Dorfman, Ariel. 1998. Heading south, looking north: A bilingual journey. New York: Farrar, Strauss, and Giroux.

11. Dörnyei, Zoltán. 2007. Research methods in applied linguistics: Quantitative, qualitative, and mixed methodologies. Oxford: Oxford University Press

12. Ellis, Rod. 1985. Understanding second language acquisition. Oxford: Oxford University Press.

13. Ellis, Rod. 1994. The study of second language acquisition. Oxford: Oxford University Press.

14. Ellis, Rod. 2008. The study of second language acquisition (2nd edition). Oxford: Oxford University Press.

15. Erdman, Sarah. 2003. Nine hills to Nambonkaha: Two years in the heart of an African village. London: Picador.

16. Faerch, C. and G. Kasper. eds. 1987. Introspection in second language research. Cleveden, Avon: Multilingual Matters.

17. George, Don and Anthony Sattin. eds. 2002. A house elsewhere: Tales of life abroad. Melbourne: Lonely Planet.

18. Hessler, Peter. 2001. River town: Two years on the Yangtze. London: John Murray.

19. Hinkel, Eli. 2011. Handbook of research in second language acquisition. vol. 2. New York: Routledge.

20. Hobson, Charlotte. 2001. Black earth city: A year in the heart of Russia. London: Granta Books.

21. Hoffman, Eva. 1989. Lost in translation: A life in a new language. London: William Heinemann. 
22. Hulme, Peter and Tim Youngs, ed. 2002. The Cambridge companion to travel writing. Cambridge: Cambridge University Press.

23. Korte, Barbara. 2000. English travel writing: From pilgrimage to post-colonial exploration. London: Macmillan.

24. Lambert, Derek. 2000. Spanish lessons: Beginning a new life in Spain. New York: Broadway Books.

25. Mayes, Frances. 1999. Bella Tuscany: The sweet life in Italy. London: Bantam Books.

26. Nunan, David. 1992. Research methods in language learning. Cambridge: Cambridge University Press.

27. Nunan, David and Julie Choi. 2011. Shifting sands: The evolving story of 'voice' in qualitative research. In Handbook of research in second language teaching and learning. vol. 2. ed. E. Hinkel, 222-236. New York: Routledge.

28. Pavlenko, Aneta. 2002. Narrative study: Whose story is it, anyway? TESOL Quarterly 36 (2): 213218. doi: $10.2307 / 3588332$

29. Pellegrino, Valerie A. 1998. Student perspectives on language learning in a study abroad context. Frontiers 4: 91-120.

30. Pellegrino, Valerie A. 2005. Study abroad and second language use: Constructing the self. Cambridge: Cambridge University Press.

31. Richards, J. C. and R. Schmidt. 2010. Longman dictionary of language teaching and applied linguistics (4th edition). Harlow: Pearson Education Limited.

32. Schmidt, R. and S. Frota. 1986. Developing basic conversational ability in a second language: A case study of an adult learner in Portuguese. In Talking to learn: Conversation in second language acquisition, ed. R. R. Day, 237-326. Rowley, MA: Newbury House.

33. Thubron, Colin. 1999. Both seer and seen: The travel writer as leftover amateur. Times Literary Supplement. July 30: 12-13.

34. Turzonska, A. 2014. Junior high school learners' ability to reflect in the process of keeping a diary in a foreign language. In Studying second language acquisition from a qualitative perspective, ed. D. Gabrys-Barker and A. Vojtaszek, 71-89. Heidelburg: Springer International Publishing.

35. Werner, Dennis. 1990. Amazon journey: An anthropologist's year among Brazil's Mekranoti Indians. Englewood Cliffs, NJ: Prentice Hall.

36. Williams, Marion and Robert L. Burden. 1997. Psychology for language teachers: A social constructivist approach. Cambridge: Cambridge University Press 